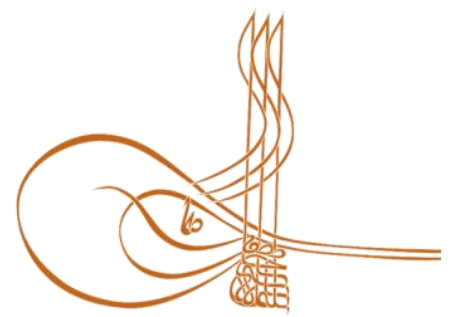

www.turkishstudies.net/economy
Turkish Studies - Economics, Finance, Politics

eISSN: $2667-5625$

Research Article / Araştırma Makalesi

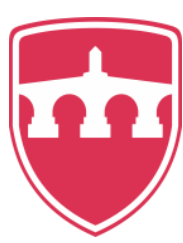

INTERNATIONAL BALKAN

UNIVERSITY

Sponsored by IBU

\title{
İşletmelerde İçsel Pazarlama Faaliyetleri ve Örgütsel Bağlılık Düzeyi Arasındaki İlişkinin İncelenmesi: Telekomünikasyon Sektöründe Bir Araştırma
}

\author{
Investigation of The Relationship Between Internal Marketing Activities and Organizational \\ Commitment Level in Businesses: An Research on Telecommunication Sector
}

\author{
Erhan Kılınç* $^{*}$ Hüseyin Koçarslan ${ }^{* *}-$ Alper Gedik $^{* * *}-$ Hasan Topcu $^{* * * *}$
}

\begin{abstract}
Traditional marketing approach, which used to be aimed at the external environment in the past, has now been replaced by a more modern marketing approach in which the employee is accepted as a customer. This approach, which is called internal marketing, reveals that there is a direct link between the quality of service and customer satisfaction and the satisfaction, attitude and behavior of the employees. Furthermore, the studies suggest that the satisfaction of the employees who are internal customers increases their loyalty to the company. The aim of this study is to determine the relationship between internal marketing activities and organizational commitment level. This cross-sectional and descriptive study was conducted on 124 people from different occupational groups working in a telecommunications company in Konya. The questionnaire consists of 37 questions, 6 of which are socio-demographic questions, 11 of which are internal marketing scale questions and 20 of which are organizational commitment scale questions. Research data were collected in January-February 2019. In the light of the information obtained from the research was calculated of the total internal marketing level of the participants as $3,5477 \pm 0,84855$; the
\end{abstract}

\footnotetext{
* Dr. Öğr. Üyesi, Selçuk Üniversitesi, Beyşehir Ali Akkanat İşletme Fakültesi, Uluslararası Ticaret ve İşletmecilik Asst. Prof. Dr., Selcuk University/Beyşehir Ali Akkanat Faculty of Business Administration, Department Of International Trade And Business 
average level of organizational commitment of employees as 3,5500 $\pm 0,58166(\min .: 1, \max .: 5)$. As a result of the research, it was found that there was a significant positive correlation between internal marketing level and organizational commitment level $(\mathrm{r}=0.595, \mathrm{p}<0.01)$. On the other hand, there is a high relationship between emotional commitment and internal marketing $(r=0.765, p<0.01)$, and a moderate relationship between normative commitment and internal marketing $(\mathrm{r}=0.461, \mathrm{p}<0.01)$. There was no statistically significant relationship between continuation commitment and internal marketing $(\mathrm{r}=0.108, \mathrm{p}>0.05)$. This shows that internal marketing activities increase employees' emotional and normative commitment, which is a kind of voluntary and strong commitment to the organization; it does not affect the continuation commitment which considers them to be an obligation. From this point of view, it can be said that increasing internal marketing level in organizations increases organizational commitment. The positive implementations of the managers in their organizations will contribute to both internal and external customer satisfaction and increase the profitability of the enterprise.

Structured Abstract: Traditional marketing approach, which used to be aimed at the external environment in the past, has now been replaced by a more modern marketing approach in which the employee is accepted as a customer. This approach, which is called internal marketing, reveals that there is a direct link between the quality of service and customer satisfaction and the satisfaction, attitude and behavior of the employees. Furthermore, the studies suggest that the satisfaction of the employees who are internal customers increases their loyalty to the company.

Organizational commitment is defined as the degree to which the employee identifies herself with the business and the degree of loyalty she exhibits towards the business. In order for employees to be productive in an enterprise; it must adopt its work and workplace and demonstrate commitment to the organization in order to do better. For this reason, it is extremely important to keep qualified employees in the enterprise and strengthen the link between the organization and employees.

Internal marketing activities of the company are of great importance for the qualified personnel to remain in the enterprise and to exhibit their loyalty. Businesses can increase organizational commitment by making use of internal marketing, evaluating the internal customer together with the external customer and using various motivated tools. This is an important factor in ensuring the profitability and continuity of enterprises.

The aim of this study is to determine the relationship between internal marketing activities and organizational commitment levels. In this context, the relationship between internal marketing and organizational commitment has been tried to be explained by a survey on telecommunication sector employees. Within this scope, the relationship between the internal marketing and organizational commitment levels of the employees and socio-demographic variables were tried to be revealed.

This cross-sectional and descriptive study was conducted on 124 people in different occupational groups in a telecommunication institution operating city of Konya in Turkey. Among the participants; There are people who carry out various tasks including manager/team leader, authorized/ responsible, engineer, technician/technician and officer/ representative working in this sector. The questionnaire consists of 37 questions, 6 of which are socio-demographic questions, 11 of which are internal marketing scale questions and 20 of which are organizational commitment scale questions. The internal marketing scale used in the research is the 'Internal Marketing Scale' en developed by Foreman and Money. The scale consists of three dimensions: 'rewarding and motivation', 'effective communication' and 'employee development'. The 'Organizational Commitment Scale' was developed by Meyer and Allen (1990). This scale consists of three dimensions called emotional, continuation and normative commitment. These scales are the most widely used in the literature. Internal Marketing Scale and Organizational Commitment Scale were arranged as 5point Likert. The research data were evaluated in SPSS package program. Data were interpreted by student $t$ test, ANOVA, Pearson correlation analysis. The validity and reliability coefficients of the research scales were calculated as 0.931 for Internal Marketing Scale and 0.873 for Organizational Commitment Scale. Research data were collected in January-February 2019.

According to the socio-demographic findings, the majority of the participants were male, married and had associate degree and higher education. In the light of the information obtained from the research was calculated of the total internal marketing level of the participants as $3,5477 \pm 0,84855$; the average level of

Turkish Studies - Economy, 15(1) 
organizational commitment of employees as 3,5500 $\pm 0,58166$ (min.:1, max.:5). As a result of the research, it was found that there was a significant positive correlation between internal marketing level and organizational commitment level $(r=0.595, \mathrm{p}<0.01)$. From this point of view, increasing internal marketing level in organizations increases organizational commitment. On the other hand, there is a high relationship between emotional commitment and internal marketing $(\mathrm{r}=0.765, \mathrm{p}<0.01)$, and a moderate relationship between normative commitment and internal marketing $(\mathrm{r}=0.461, \mathrm{p}<0.01)$. There was no statistically significant relationship between continuation commitment and internal marketing $(r=0.108, p>0.05)$. This shows that internal marketing activities increase employees' emotional and normative commitment, which is a kind of voluntary and strong commitment to the organization; it does not affect the continuation commitment which considers them to be an obligation. Associate degree graduates, undergraduate and graduate education graduates were found to be more dependent on their organizations $(p<0.05)$. It was found that men had higher levels of internal marketing and organizational commitment than women ( $>0.05)$.

Although there are many factors that are effective in conducting internal marketing activities and increasing organizational loyalty in enterprises, the most important and responsible persons are managers. Managers must go beyond the classical management approach to ensure the satisfaction of their employees and motivate them. If they are able to achieve this, both the quality of the services provided increases and customer satisfaction is ensured. The positive implementations of the managers in their organizations will contribute to both internal and external customer satisfaction and increase the profitability of the enterprise.

Keywords: Internal Marketing, Organizational Commitment, Telecommunication Sector

Öz: Eskiden tamamen dış çevreyi hedeflenerek yürütülen geleneksel pazarlama anlayışı, günümüzde yerini çalışanın da müşteri olarak kabul edildiği daha modern bir pazarlama yaklaşımına bırakmıştır. İçsel pazarlama olarak adlandırılan bu yaklaşım, işletmelerde (özellikle emek yoğun işletmelerde) sunulan hizmetin kalitesi ve müşteri memnuniyeti ile çalışanın memnuniyeti, tutum ve davranışları arasında doğrudan bir bağlantı olduğunu ortaya koymaktadır. Ayrıca yapılan çalışmalar, iç müşteri olan çalışanların memnuniyetinin onların işletmeye olan bağlılığını artırdığı ileri sürmektedir. Bu çalışmanın amacı, işletmelerde içsel pazarlama faaliyetleri ile örgütsel bağlılık düzeyi arasındaki ilişkinin belirlenmesidir. Kesitsel ve betimleyici olarak yapılan bu araştırma, Konya'da bir telekomünikasyon işletmesinde görev yapan farklı meslek grupları içerisindeki 124 kişi üzerinde anket uygulaması şeklinde gerçekleştirilmiştir. Anket formu, altısı sosyo-demografik soru olmak üzere, 11'i içsel pazarlama ölçeği sorusu ve 20'si örgütsel bağlılık ölçeği sorusu olmak üzere toplam 37 sorudan oluşmaktadır. Araştırma verileri, 2019 yılında OcakŞubat ayları içerisinde toplanmıştır. Araştırmadan elde edilen bilgiler 1şı̆̆ında katılımcıların toplam içsel pazarlama düzeyi ortalamasının 3,5477 $\pm 0,84855$; çalışanların örgütsel bağlılık düzeyinin ortalamasının

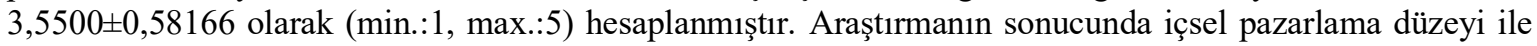
örgütsel bağlılık düzeyi arasında pozitif yönlü orta düzeyde $(r=0,595, p<0,01)$ anlamlı bir ilişki olduğu saptanmıştır. Diğer taraftan örgütsel bağlılığın alt boyutlarından duygusal bağlılık ile içsel pazarlama arasında $(r=0,765, p<0,01)$ yüksek bir ilişki, normatif bağlılık ile içsel pazarlama arasında $(r=0,461, p<0,01)$ orta düzey bir ilişki saptanırken; devam bağlılığı ile içsel pazarlama arasında $(r=0,108, p>0,05)$ istatistiksel olarak anlamlı bir ilişki saptanmamıştır. Bu da göstermektedir ki, içsel pazarlama faaliyetleri, çalışanların örgüte karşı gönüllü ve kuvvetli bir bağlılık türü olan duygusal ve normatif bağlılıklarını arttırmakta; örgütte kalmalarını bir zorunluluk olarak gören devam bağlılığını ise etkilememektedir. Buradan hareketle, örgütlerde içsel pazarlama düzeyinin artmasının örgütsel bağlılığı artırdığı söylenebilir. Örgütlerde yöneticilerin çalışanlarına dair yapacakları olumlu uygulamaları, hem iç ve dış müşteri memnuniyetinin sağlanmasında hem de işletme karlılığının artmasında katkılar sağlayacaktır.

Anahtar Kelimeler: İçsel Pazarlama, Örgütsel Bağlılık, Telekomünikasyon Sektörü

\section{Giriş}

Eskiden tamamen dış çevreyi hedeflenerek yürütülen geleneksel pazarlama anlayışı, günümüzde yerini çalışanın da müşteri olarak kabul edildiği daha modern bir pazarlama yaklaşımına bırakmıştır. Bu yaklaşım, işletmelerde (özellikle emek yoğun işletmelerde) sunulan hizmetin kalitesi ve müşteri memnuniyeti ile çalışanın tutum ve davranışları arasında doğrudan bir 
bağlantı olduğu görüşünü ileri sürmektedir. Müşteri memnuniyeti için çalışanların memnuniyetini önemseyen bu anlayış 'İçsel Pazarlama' olarak adlandırılmıştır.

Günümüzde artan rekabet koşulları ve teknolojik gelişmeler, işletmelerin insan kaynağını daha verimli ve daha etkili kullanılmasına yöneltmiştir. İşletmeler verimlilik ve maliyet esaslı olarak daha az girdi ile daha çok çıktı elde etmek isterler. Bu da insan kaynağının o işletmede (örgütte) çalışmaya istekli olması ve elinden gelen gayreti göstermesi ile mümkündür. Örgütlerde bağl1lık olarak adlandırılan bu isteklilik, günümüzde örgütte performans ve verimlilik gibi bir başarı ve değerlendirme ölçütü haline gelmiştir. Diğer taraftan örgütlerde çalışan bağl11ı̆̆ının bu kadar önemli olmasının nedeni, özellikle çalışanların çok çabuk kaybedilebilme ihtimalini söz konusu olması ve bunun getireceği işletmeye maliyetlerle ilgilidir.

Örgütsel bağlılık kavramının birçok tanımı olmakla birlikte, kısaca, çalışanın işletme ile kendini özdeşleştirmesi ve işletmeye karşı sergilediğini sadakat derecesi tanımlanabilir. Bir işletmede çalışanların işlerinde verimli olabilmeleri için işini ve işyerini benim sahiplenip daha iyisini yapabilmek için örgüte bağl1lık hissetmesine ihtiyaç vardır. Bu noktada işletmelerin çalışanlarını (özellikle kalifiye ve kilit noktada çalışanları) işletmede tutmaya çalışması ve onların örgütle olan bağlarını güçlendirilmesi önem arz etmektedir.

Örgütlerde işgören bağlılığının sağlanmasında, işletmenin yaptı̆̆ 1 içsel pazarlama faaliyetlerinin de katkısı büyüktür. İşletmeler, içsel pazarlama faaliyetleri ile iç müşteriyi de dış müşteri ile birlikte değerlendirerek, onlara gerekli önemi ve değeri vererek ve çeşitli motive araçları kullanarak örgütsel bağlılığı artırılabilirler. Bu da işletmelerin karlılığının ve sürekliliğin sağlanmasında dikkate alınması gereken bir husustur. Bu nedenle çalışanın örgütsel bağlılığ sağlanmada, içsel pazarlamada uygulanan stratejilere ihtiyaç duyulur.

Günümüz rekabet koşullarında ayakta kalmak ve devamlılıklarını sürdürmek isteyen işletmelerin, çalışanların örgüte olan bağlılıklarını arttırılmasını sağlayacak ve işten ayrılma niyetlerini minimum düzeye düşmesini sağlayacak olan içsel pazarlama faaliyetlerine odaklanmaları ve bu faaliyetleri geliştirmeleri gerekmektedir (Yüce ve Kavak, 2017: 79).

Bu çalışmanın amacı, işletmelerde içsel pazarlama faaliyetleri ile örgütsel bağlılık düzeyi arasındaki ilişkinin belirlenmesidir. Bu kapsamda çalışanın başında ilgili literatür eşliğinde içsel pazarlamanın tanımı, amacı, önemi, yararları ve boyutları ile örgütsel bağlılığın tanımı, önemi ve boyutları açıklanmıştır. Çalışmanın devamında içsel pazarlama ve örgütsel bağlılık arasındaki ilişki, Konya ilinde faaliyet gösteren bir telekomünikasyon kurumunda çalışanlar üzerinde yapılan bir anket çalışmasıyla açıklanmaya çalışılmıştır.

\section{Kavramsal Çerçeve}

\section{1. İçsel Pazarlama}

Günümüz dünyasında küreselleşme ile birlikte işletmelerin varlıklarını sürdürebilmeleri, giderek daha da zorlaşan rekabet koşullarında ayakta kalabilmeleri ve başarılı bir şekilde amaçlarına ulaşabilmeleri için çeşitli ve farklılık yaratacak uygulamaları ön plana çıkarmaları gerekmektedir. Bu uygulamaların fark edilmesinde ve hayata geçirilmesinde en önemli faktör insan kaynağıdır (Yüce ve Kavak, 2017: 79). Bu anlamda işletmelerin varlıklarını sorunsuz bir şekilde sürdürebilmeleri, çalışanların işletmeye olan katkıları ve onların devamlılıklarıyla yakından ilişkilidir.

Diğer taraftan işletmeler salt ekonomik ve teknik birimler değildirler; aynı zamanda insani ve sosyal organizasyonlardır. İşletmelerin sosyal ve insani yönlerinin eksik olması ya da hiç olmaması işletmelerin geleceğini tehdit edebilecek bir durumdur. Bundan dolayı işletmelerin çalışan personeline gereken önemi vermesi, onların işletmeye olan güvenlerini sağlaması ve bu suretle çalışanların işletmede kalması için çabalar sarf etmesi gerekmektedir (Kotler, 2005: 16; Demirel, 2009: 269). 
İşletmeler uygulamada bu durumu gerçekleştirmek için zaman zaman bazı zorluklarla karşı karşıya kalabilmektedirler. Bunun en büyük nedenleri arasında bazı örgütlerin, çalışanlarını sadece işini yapmakla yükümlü olan veya onları bir sistemin veya bir makinenin bir parçası olarak görme düşüncesi ve yaklaşımı vardır. Bu noktada çalışanların sosyal ve psikolojik yönü göz ardı edilmektedir. Diğer taraftan çalışanlarını işletme ve yönetimin bir parçası olarak algılayan ve onları tüm örgüt süreçlerde aktif rol oynaması için teşvik eden örgütlerde ise durumun daha farklı olduğu görülmektedir. Bu tür örgütlerde çalışanlar, örgütü içten benimseyerek ona bir şeyler katabilmenin mutluğunu yaşamaktadırlar. Bunun için çalışanların, kendilerini önemli bir iş yapan ve işletmeye katkıda bulunan bir kişi görmeleri ve organizasyonun bir parçası olduklarını hissetmeleri gerekir. Dolayısıyla işletmeler sadece müşteriler için değil, çalışanlar içinde bir değer önermesi hazırlamalıdır (Kotler, 2005: 16; Demirel, 2009: 269). Örgütün çalışanlarına yönelik olarak uygulayacağı içsel pazarlama faaliyetleri bu anlamda işletmelere oldukça önemli kazanımlar sağlamaktadır.

İçsel pazarlama ile ilgili literatürde birçok tanım bulunmaktadır. İçsel pazarlama kavramının öncüsü olarak görülen Berry, çalışanları iç müşteri olarak ele almak gerektiğini ve söz konusu örgütün hedeflerine ulaşmak için iç müşterilerin (çalışanların) istek ve ihtiyaçlarının karşılanması gerektiğini vurgulamıştır (Berry, 1981). Kotler (2003) ise içsel pazarlamayı; çalışan personelin müşterilerin memnuniyet ve sadakatini sağlayacak hizmetler sunabilmeleri için, eğitilmesi, motivasyon düzeylerinin arttırılması ve iyi bir ücretlendirme sisteminin kurulmas1 faaliyetlerden meydana gelen bir süreç olarak tanımlamıştır. Diğer bir tanımda ise içsel pazarlama; pazarlama uygulama ve felsefesinin dişsal müşterilere en iyi hizmet vermesi amacı ile işletme çalışanlarına uygulanması sürecidir (Greene vd.,1994: 8).

İçsel pazarlama konseptini oluşturan öncü araştırmacı Berry (1981), çalışanların müşteri olduğunu ve diş müşterilere benzer şekilde tatmin edilmeleri gerektiğini ileri sürmüştür. Berry (1981) yaptığı çalışmalarda, çalışanın iş tatminini teşvik etmek ve geliştirmek için farklı türde iç iletişim ve tanıtım yöntemleri geliştirmeyi amaçlamıştır. Bu durum başarıldığında yani iç müşteri tatmin edildiğinde, dış müşterilerin memnuniyeti ve sadakatinin etkin bir biçimde artacağı öne sürülmüştür (Ismaila ve Sheriffb, 2016:200).

Rafiq ve Ahmet (2000) içsel pazarlamayı, müşteri memnuniyetini sağlamak amacıyla, çalışanların kurumsal ve fonksiyonel stratejilerin etkili bir şekilde uygulanmasına yönelik olarak yönlendirilmesi, motive edilmesi, örgütsel direncin üstesinden gelmek için pazarlama benzeri bir yaklaşım kullanarak planlanmış bir dizi çaba olarak tanımlamıştır. Aynı zamanda bu kavram, motive olmuş ve müşteri odaklı çalışan personel oluşturma süreci olarak da tanımlanmıştır. Müşteri ihtiyaç ve beklentilerine cevap verebilen müşteri odaklı çalışanlara sahip olmak bu sürecin temel özelliğidir (Varinli, 2012: 111).

\section{2. İçsel Pazarlamanın Amacı ve Önemi}

İçsel pazarlama faaliyetlerinin temel amacı; dış müşterilerin memnuniyetini ve sadakat düzeylerini arttırmak için örgüt yönetiminin işgören ihtiyaçlarını dikkate alması ve onların motivasyonların artırmasıdır (Yüce ve Kavak, 2017: 79). İçsel pazarlamanın sağlayacağı en büyük avantaj; nitelikli işgörenlerin işletmeye çekilmesi, onların geliştirilmesi ve motive edilerek işletmede kalmalarının sağlanması hususları sayılabilir (Kocaman vd., 2013: 22). Bu noktada içsel pazarlama, çalışanlara bir müşteri grubu gibi davranmayı amaçlamaktadır. Bunun için, en büyük örgütlerin bile, en alt kademedeki çalışanlarının kendini iyi hissetmesi için çaba göstermesi gerekmektedir (Kotler, 2005: 16).

İçsel pazarlama, etkin pazarlama stratejileri geliştirmek ve uygulamak için, iş organizasyonlarında çalışanların bilgi düzeyini arttırmaya ve onları çeşitli süreçlere daha fazla dâhil etmeye çalışan bir dizi sistemin kullanılması uygulamalarını içermektedir. İçsel pazarlama kavramı, çalışanların iş organizasyonlarında tüm süreçlere katılımının sağlanması ve iş tatmini 
düzeylerinin ve bağlılı̆̆ın geliştirilmesi konularına odaklandığından ve işletmelerde rekabet avantajı geliştirme stratejilerinden biri olarak görüldüğünden araştırmacıların ve bilim adamlarının dikkatini çekmiştir (Bowen ve Schneider, 2014). Sektör farketmeksizin tüm işletmeler tarafindan uygulanabilen içsel pazarlama yaklaşımı, iç müşteriler ile dış müşterilerin yüksek temasta olduğu ve işgücü yoğun bir şekilde faaliyet gösteren hizmet sektörü için çok daha önemli bir olgudur (Varinli, 2008: 110)

Opoku vd. (2009) tarafindan yapılan çalışmada içsel pazarlama faaliyetlerini başarı ile yürüten işletmelerde işgören devir hızının daha düşük olacağını, çalışanların tatmin düzeylerinde artışlar yaşanacağını, hizmetin kalitesinde artışlar olacağını aynı zamanda da değişime karşı direncin etkisinin azalacağının ileri sürmüştür.

\section{3. İçsel Pazarlamanın Yararları}

Dış müşterilerin tatmini, iç müşteriler tarafindan sağlanmaktadır ve iç müşterilerin tutum ve davranışlarının dış müşterilerin memnuniyeti ve sadakati ile doğrudan bir ilişkisi bulunmaktadır (Doğan ve Kılıç, 2008). Özellikle işgücü yoğun olarak çalışılan alanlarda hizmet kalitesi, çalışanın becerisine ve tutumuna bağlıdır (Varinli, 2008: 108). Bu nedenle içsel pazarlama, dış müşterilerin beklentilerinin karşılama açısından kilit bir role sahiptir (Dündar ve Fırlar, 2006: 132).

İçsel pazarlama uygulamaları kullanılarak iyileştirilen hizmet kalitesi aracılığıyla oluşan karlılık artışı sayesinde işletmeler, normalden fazla pazar payı büyümesi yaşayabileceklerdir (Zeithaml, Berry ve Parasuraman, 1996: 31). Başarılı bir şekilde uygulanan içsel pazarlama faaliyetlerinin dört temel yararı aşağıda verilmiştir (Arnet, Laviere ve Mclane, 2002: 87-88):

- İşten ayrılma oranının düşmesi,

- Çalışan tatmininin artması,

- Organizasyondaki değişime tepkilerin azalması,

- Hizmet kalitesinin artmas1.

\section{4. İçsel Pazarlamanın Boyutları}

Ödül ve motivasyon: İçsel pazarlamada, iç müşterilerin dış müşterilerin istek ve beklentilerini anlayabilmeleri ve ihtiyaçlarını zamanında karşılayabilmeleri için bilgilendirilmeye, motivasyona ve ödüllendirilmeye ihtiyaçları vardır (Doukakis ve Kitchen, 2004: 421). Ödüllendirme ve motivasyon içsel pazarlamanın iş tatmini ile ortak paydasıdır. Ödüllendirme güçlü bir motivasyon kaynağıdır.

Etkili İletişim: İçsel iletişim "yönetim ile kuruluşta çalışanların tüm iletişim biçimleri" olarak ifade edilmektedir (ElSamen ve Alshurideh, 2012: 86). Bu tanımı biraz daha genişletmek gerekirse; İşletmenin kurumsal amaç ve hedefleri ulaşmak ve faaliyetlerini sürdürmek için işletmeyi oluşturan bölümler ve çalışanlar arasında koordinasyon, bilgi akışı, motivasyon, uyum, eğitim ve karar alma süreçlerini sağlamak amacıyla gerçekleştirilen tüm süreçler, örgütlerde etkili iletişim unsurları içerinde sayılabilmektedir (İşler ve Özdemir, 2010:118).

İsgören Gelişimi: İşletmeler hedeflerine ulaşabilmek için sürekli eğitim merkezleri ile çalışanlarını eğitmeli ve onları tam donanımlı hale getirmelidir. Çalışanı geliştirmek için dört yaklaşım kullanılmaktadır: biçimsel eğitim, değerlendirme, iş tecrübeleri ve kişilerarası ilişkiler. Birçok organizasyon, bu yaklaşımların bileşimini kullanır (Noe, 1999, 251). Kişisel gelişim eğitimleri aynı zamanda işletmeler için bir motivasyon aracıdır.

\section{5. Örgütsel Bağlılık}

Örgütsel bağlılık kavramı, 1956 yılından bu yana süregelen araştırmalarda sıklıkla kullanılan bir kavramdır. Çalışanların iş verimliliklerini açıklaması nedeniyle son yıllarda sıklıkla 
incelenir hale gelmiştir (Wasti, 2000: 401). Zaman içerisinde gelişen bu kavramın önemli modelleri de oluşmuştur. Örgütsel bağlllık ile ilgili geliştirilen modeller, kronolojik sıralamaya göre aşağıdaki gibi sıralanabilir (Sezgin ve Ünlüönen, 2011: 7):

i. Devamlılık Bağlılı̆̆ Modeli (Becker, 1960),

ii. Duygusal Bağl1lık Modeli (Mowday, Steers ve Porter, 979),

iii. Normatif Bağlılık Modeli (Weiner ve Vardi, 1980),

iv. Üç Boyutlu Örgütsel Bağlılık Modeli (Meyer ve Allen, 1991); devamlılık bağgl1lğı, duygusal bağl1lık ve normatif bağlilık.

Örgütsel bağl1lı̆̆ın organizasyon için önemini, kapsamını ve etkisini öğrenmek için farklı araştırmacılar tarafından çeşitli ölçekler geliştirilmiştir. Zamanla tek boyutta inceleyen ölçeklerin yetersizliği nedeniyle çok boyutlu bir ölçek geliştirme çalışmaları başlamıştır. Meyer ve Allen'ın üç boyutlu bağlılık ölçeği, bu alanda en çok kullanılan ve araştırılan ölçektir (Eğriboyun, 2014: 31). Örgütsel bağl1lık, çalışan ve örgüt arasında doğrudan bir ilişkiyi vurgulamasına rağmen, bu ilişkinin yapısı ve oluşumu ile ilgili görüş farklılıkları vardır. Bu durum örgütsel bağl1lığın farklı tanımlarının ortaya çıkmasına neden olmuştur (İnce ve Gül, 2005: 3). Bazı örgütsel bağlılık tanımları aşağıda verilmiştir.

- Örgütsel bağl1lık, kişinin örgüte duygusal olarak bağlanması, örgütten ayrılma durumunda oluşacak maliyetlerin öngörmesi ve örgütte kalmak için bir zorunluluk hissetme halidir (Tekin vd. 2014: 138).

- Örgütsel bağll1ık bireyin kuvvetli bir şekilde organizasyon ile özdeşleştirmesi ve örgüte dâhil olma işlevidir (Köse ve Özer, 2013: 93).

- İşgörenin, örgüte dâhil olma, onun amaç ve değerlerini benimseme ve örgütte devam etme isteği, onunla maddi kaygılar gütmeksizin özdeşleşmesi ve çalışanın işyerine psikolojik olarak bağlanmasıdır (Balay, 2000: 16).

- Çalışanın örgütsel bağ 11 lı̆̆ işletmenin etkinliği, çıkarı ve başarısı ile kimlikleşmesidir (İbicioğlu, 2000: 13).

- Bir grup insanın, iş ve görev bölümü yaparak bir otorite ve sorumluluk hiyerarşisi içinde ortak ve açık bir amacın gerçekleştirilmesi için birlikte hareket edilmesidir (Tutar, 2009: 15).

Örgütsel bağlılık, çalışanın bazı faktörlerin etkisinde kalarak çalıştı̆̆ örgüt için kendisini sorumlu hissetmesi ve örgütün devamlılığı için çalışmak istemesidir. Diğer bir ifadeyle örgütsel bağl1lık, kişinin örgüte sadakat ve aidiyet duygusu, yardım etme isteği ve örgütün hedeflerine ulaşma konusunda elinden gelen gayreti gösterme çabalarıdır. Kişilerin örgütsel bağlılıklarını sadece psikolojik etkenler ile açıklamak doğru değildir. Bunun yanında fiziksel koşullar ve maddi olanaklar da kişinin örgütsel bağl1lı̆̆ını etkilemektedir. Örgütsel bağlılıkta en önemli faktör yöneticilerdir. Kişilerin işten ayrılmalarının nedeni kimi zaman işletme ile ilgili olmamakta ve işletme yöneticisi ile ilişkili olabilmektedir. Şirket politikaları, içsel pazarlama faaliyetleri ile çalışanı ve aynı zamanda müşteriyi de odağına alarak çeşitli motive araçları ile çalışana saygınlık kazandırmakta ve örgütsel bağl1lığı güçlendirmektedir.

\section{6. Örgütsel Bağlılığın Önemi}

Örgütsel bağl1lık, örgütlerin hedeflerine ulaşabilmeleri için takım ruhu ile hareket eden çalışanlar kazandırdığı gibi çalışanlar açısından da bir gruba (örgüte) dâhil olma toplum içinde yer edinme açısından faydalı olmaktadır. İşgörenlere örgütsel bağlılık sağlayacak pek çok etken olmakla birlikte; ücretler, primler, örgütsel kültür ve liderlik, özel hayatla iş hayatı arasındaki denge, bireysel özellikler, genel yönetim politikaları, işyerinde eğitim ve gelişim olanakları, işverenin kurumsal imajı gibi çıkarlar bunların başında gelmektedir (Durna ve Eren, 2005).

İşletmelerde örgütsel bağl1lı özellikle personel devri, motivasyon, iş tatmini ve performans olguları ilişkilidir. Personel devir oranı yüksek olan işletmeler, yöneticilerini, kontrolü zor ve birbiriyle bağlantılı pek çok işgören sorunuyla karşı karşıya bırakmaktadır. Personel devir 
hızı, aday toplama, eğitim ve terfi gibi birçok insan kaynakları uygulamalarında ve stratejileride doğrudan etkisi olan bir problemdir (Kitapçı ve Elçi, 2007: 143). Örgütsel bağl1lığın olmaması ya da yetersiz olması durumunda, işletmelerde ideal olmayan personel devir oranı ortaya çıkabilmektedir.

Örgütsel bağlılık üzerinde etkisi olan motivasyon kavramı ise; çalışanların işe başlamalarını, devam etmelerini ve görevlerini istekle yerine getirmelerini sağlayan bütünsel fonksiyonların tümüdür (Özalp, 1994: 440). Bu anlamda motivasyon işgörenlerin bağl1lı̆̆ını artırdığı söylenebilir.

İş tatmini, iş görenin işine karşı olumlu ya da olumsuz tutum ve davranışların bütünüdür. Çalışanların yaptıkları işin beklentilerini karşılayıp karşılamadığı, örgüte olan bağlılığını etkilemektedir. Yapılan işin özellikleri; tehlikesiz iş olması, stressiz olması, bağımsız olması, iş güvenliği sağlanması, işten elde edilen kazançların yeterli olması gibi beklentileri karşıllyorsa örgüte olan bağll1ık da artmaktadır (Demirel, 2009: 118).

İş tatmini örgüt açısından önemli bir olgudur; çalışanın verimini arttırdığı gibi tatminsizlik durumunda verimlilik düşebilmektedir. Örgütlerde iş tatminsizliği; çalışanlarda işe devamsızlık, iş gücü devir hızı, stres, fiziksel ve ruhsal bozukluklar, örgüt içi uyumsuzluk gibi etkiler ortaya çıkarmaktadır (Izgar, 2003: 152).

Örgütsel bağlılık ve çalışan performansı arasındaki ilişkinin anlamlı olabilmesi için çalışanın kişilik özelliklerinin yanında, ödül, eşitlik duygusu ve diğer destekleyici unsurların da olması gerekir. Örgütsel bağl1lı̆̆1 yüksek çalışanın düşük olan çalışandan daha fazla performans göstermesi beklenir (Akınc1, 2002: 18).

\section{7. Örgütsel Bağlılığın Boyutları}

Mowday ve arkadaşları (1979) yaptıkları çalışmalarda örgütsel bağl1lık, kişinin örgüte karş1 hissettiği duygusal bağl1lık olarak tek boyutlu açıklamaya odaklanırken; daha sonraki çalışmalar örgütsel bağlılığın çok yönlü yapısının olduğunu ortaya koymuşlardır (Chordiya, 2017: 180; Reichers, 1985: 468). Literatür incelendiğinde örgütsel bağl1lığın genel olarak çok boyutlu olduğu görüşü hâkimdir (Bakan, 2011: 12). Meyer ve Allen örgütlerdeki bağl1lı̆̆g ilk başta duygusal bağlılık ve devamlılık bağl1lığı olmak üzere iki boyutta ortaya koymuştur. Daha sonra yapılan çalışmalar örgütsel bağ l1lığı; tutumsal (duygusal) bağl1lık, davranışsal bağlılık, devam etme bağlılı̆̆1 ve normatif (zorunluluk) bağlılık olmak üzere dört başlık daha kapsamlı olarak araştırılmasına yol açmıştır (Bakan, 2011: 12; Uygur, 2015:8; Pinks, 1992: 4).

Duygusal (Tutumsal) Bağgllık: Duygusal bağlılık, çalışanların örgütün değerlerini, amaçlarını ve amaçlarını duygusal olarak benimseme derecesidir. Bu bağlılıkta çalışanlar işletmenin değerlerini güçlü bir istekle ile kabul eder ve onun bir parçası olarak kalmak isterler. Duygusal bağl1lık, örgütsel bağl1lığın "arzu" bileşeni olarak nitelendirilmektedir. İşgören, organizasyonel değerlerle kendi kimliğini örtüştürmeye başladığında duygusal bağlılık geliştirir. Örneğin, bir çalışan, örgütün çalışanlarına karşı yeterince adil, saygın ve destekleyici olduğunu düşünürse örgütüne karş1 etkili bir biçimde bağl1lık sergileyecektir. Duygusal bağl1lık, örgütsel bağl1lığın en iyi, en güçlü, en istenilen, en kalıcı, merkezi ve vazgeçilmez boyutu olarak görülür. Bu bağl1lığa sahip bireyler, her işverenin ve yöneticinin hayalini kurduğu, gerçekten kendini örgüte adamış ve sadık kimselerdir. Bu işgörenler, işe karşı olumlu tutum sergilerler ve gerektiğinde ekstra çaba (örgütsel vatandaşlık davranışı) göstermeye hazırdırlar (Bayram, 2005: 132; Eren, 2015: 557; Mercurio, 2015: 405; Mowday, 2013; Imran and Aziz, 2017:955; Çakınberk, 2011: 107). Bu bağl11ık türü, örgütsel amaç ve değerlere ilişkin duyulan inancı ifade etmektedir (Bakan, 2011: 286; Karim, 2017: 91; Chordiya, 2017: 180).

Devam Bağlllığl: Devam bağlılığı işgörenin örgüt üyeliğinin sürdürerek örgütte kalması ve örgütün devamlılığı için kendini adamasıdır (Çakınberk, 2011: 102). İşgörenlerin örgütlerine 
yaptıkları yatırımların, harcadıkları zamanın (yıllar) ve çabaların boşa gitmemesi düşüncesi ile örgütte kalmalarının bir zorunluluk olduğunu dair inançları sonucunda oluşan bağlılıktır (Bayram, 2005:133). Bu bağl1lık türü, işgörenin işten ayrılmanın maliyetinin işte kalmanın maliyetinden daha büyük olduğu hesabına dayanmaktadır. İşgören örgütte kalmayı daha karlı bulursa bağlılık duygusu ortaya çıkacaktır (Çakınberk, 2011: 102). Bu bağl1lık, çalışanların işyerlerinden sağladıkları maddi ve psiko-sosyal çıkarlar nedeniyle ortaya çıkmaktadır (Eren, 2015: 556).

Davranışsal Bağllık: Davranışsal bağlılık, bireylerin geçmiş deneyimleri, davranışları ve örgüte uyum durumlarının, onların örgüte bağll1ık hissetme ve uyum sağlama süreçleri üzerinde etkisi olduğunu ileri sürmektedir (Uygur, 2015: 27; Bayram, 2005: 129). Çalışanlar, kendi davranışlarını, örgütün beklentilerine göre ayarlar ve uyumlu kılmak için çaba sarf ederler (Eren, 2015: 557). Davranışsal bağlılık, örgütün kendisinden ziyade, bireylerin belli bir örgütte çok uzun süre kalma durumu ve bu durumu hangi faaliyetlerle sürdürdükleri ilgili bir kavramdır (Bayram, 2005: 129). Davranışlardaki bu değişim, kişisel ve önemli bir fedakârlık ve de örgütte uzun süre kalma isteği olarak yorumlanabilir (Eren, 2015: 557).

Normatif (Zorunluluk) Bağlılık: Çalışanlar, örgüte karşı bir minnettarlık, bir vefa duygusu hissettiklerinden örgütte kalmaya devam ederler. Bunun en önemli nedeni, işverenlerin onlara gerçekten çok ihtiyaçları bir zamanda örgütlerini bırakmanın doğru olmayacağı düşüncesidir. Çünkü bu durum onları ilk başta kendini işe alan işyerine karşı yapılacak bir vefasızlık olarak görülmektedir. Bu kişiler, örgütün kendilerine sağladığı olumlu ortamın karşılığının örgütte bir süre daha çalışmaya devam ederek örgüte karşı vefa borçlarını ödemek olduğunu savunurlar (Bayram, 2005: 133). Bu durum ve bu düşünce tarzı, normatif bağlılı̆̆ın temelini oluşturmaktadır.

\section{Araştırmanın Metodolojisi}

\subsection{Araştırmanın Amacı}

$\mathrm{Bu}$ çalışmanın amacı, işletmelerde içsel pazarlama faaliyetleri ile örgütsel bağlılık düzeyleri arasındaki ilişkinin belirlenmesidir. Bu kapsamda içsel pazarlama ve örgütsel bağl1lık arasındaki ilişki, Telekomünikasyon sektörü çalışanları üzerinde yapılan bir anket çalışmasıyla açıklanmaya çalışılmıştır. Bu temel amaç kapsamında çalışanların içsel pazarlama ve örgütsel bağlılık düzeyleri ile sosyo-demografik değişkenler arasındaki ilişki de ortaya konmaya çalışılmıştır.

\subsection{Araştırma Hipotezleri}

$\mathbf{H}_{1}$ : İşletmelerde çalışanların içsel pazarlama ile örgütsel bağlılık düzeyleri arasında istatistiksel olarak anlamlı bir ilişki vardır.

$\mathbf{H}_{2}$ : Sosyo- demografik değişkenlere göre çalışanların içsel pazarlama düzeyleri arasında istatistiksel olarak anlamlı bir farklılık vardır.

$\mathbf{H}_{2.1}$ : Cinsiyet değişkenine göre çalışanların içsel pazarlama düzeyleri arasında istatistiksel olarak anlamlı bir farklılık vardır.

$\mathbf{H}_{2.2}$ : Medeni durum değişkenine göre çalışanların içsel pazarlama düzeyleri arasında istatistiksel olarak anlamlı bir farklılık vardır.

$\mathbf{H}_{2.3}$ : Yaş değiş̧kenine göre çalışanların içsel pazarlama düzeyleri arasında istatistiksel olarak anlamlı bir farklılık vardır.

$\mathbf{H}_{2.4}$ : Meslek değişkenine göre çalışanların içsel pazarlama düzeyleri arasında istatistiksel olarak anlamlı bir farklılık vardır.

$\mathbf{H}_{2.5}$ : Eğitim durumu değişkenine göre çalışanların içsel pazarlama düzeyleri arasında istatistiksel olarak anlamlı bir farklılık vardır. 
$\mathbf{H}_{2.6}$ : Toplam mesleki çalışma yılı değişkenine göre çalışanların içsel pazarlama düzeyleri arasında istatistiksel olarak anlamlı bir farklılık vardır.

$\mathbf{H}_{3}$ : Sosyo- demografik değişkenlere göre çalışanların örgütsel bağlılık düzeyleri arasında istatistiksel olarak anlamlı bir farklılık vardır.

$\mathbf{H}_{3.1}$ : Cinsiyet değişkenine göre çalışanların örgütsel bağl1lık düzeyleri arasında istatistiksel olarak anlamlı bir farklılık vardır.

$\mathbf{H}_{3.2}$ : Medeni durum değişkenine göre çalışanların örgütsel bağlılık düzeyleri arasında istatistiksel olarak anlamlı bir farklılık vardır.

$\mathbf{H}_{3.3}$ : Yaş değişkenine göre çalışanların örgütsel bağlılık düzeyleri arasında istatistiksel olarak anlamlı bir farklılık vardır.

$\mathbf{H}_{3.4}$ : Meslek değişkenine göre çalışanların örgütsel bağl1lık düzeyleri arasında istatistiksel olarak anlamlı bir farklılık vardır.

$\mathbf{H}_{3.5}$ : Eğitim durumu değişkenine göre çalışanların örgütsel bağlılık düzeyleri arasında istatistiksel olarak anlamlı bir farklılık vardır.

$\mathbf{H}_{3.6}$ : Toplam mesleki çalışma yılı değişkenine göre çalışanların örgütsel bağl11ık düzeyleri arasında istatistiksel olarak anlamlı bir farklılık vardır.

\subsection{Tasarım ve Veri Toplama Yöntemleri}

$\mathrm{Bu}$ çalışma, tanımlayıcı ve kesitsel bir araştırmadır. Araştırma kapsamında Konya ilinde faaliyet gösteren bir telekomünikasyon kurumunda görev yapan toplam 124 çalışana anket uygulanmıştır. Çalışmaya katılanlar; bu sektörde görev yapan yönetici/ekip lideri, yetkili/sorumlu, mühendis, tekniker/teknisyen ve memur/temsilci gibi kişilerden oluşmaktadırlar. Veriler 2019 yılı Ocak-Şubat ayları içerisinde toplanmıştır.

Anket formu, altısı sosyo-demografik, 11'i içsel pazarlama ve 20'si ise örgütsel bağl1lık olmak üzere toplam 37 sorudan oluşmaktadır. Araştırmada kullanılan içsel pazarlama ölçeği, Foreman ve Money tarafindan geliştirilen 'İçsel Pazarlama Ölçeği'dir. Söz konusu ölçek 'ödüllendirme ve motivasyon', 'etkili iletişim' ve 'işgören gelişimi' olmak üzere 3 boyut oluşmaktadır. Örgütsel bağl1lık ölçeği, Meyer ve Allen (1990) tarafindan geliştirilen 'Örgütsel Bağl11ık Ölçeği’ kullanılmıştır. Ölçek; duygusal, devam ve normatif bağlılık adı altında üç kısım oluşmaktadır ve literatürde en yaygın olarak kullanılan ölçektir. Bu ölçekler ülkemizde birçok çalışmada kullanılmış olup, geçerli ve güvenirlilikleri test edilmiştir.

İçsel Pazarlama Ölçeği ve Örgütsel Bağl1lık Ölçeği 5'li Likert şeklinde düzenlenmiştir. kesinlikle kat1lyorum (5), kat1lıyorum (4), ne kat1liyorum ne de katılmiyorum (3), katılmiyorum (2), kesinlikle katılmıyorum (1) olarak puanlanmıştır. İki ölçekte de ortalamanın yüksek olması, içsel pazarlama ve örgütsel bağl111k düzeyinin yüksek olduğunu göstermektedir.

\subsection{Veri analizi}

Araştırma verileri SPSS paket programında değerlendirilmiştir. Veriler, Student t testi, ANOVA, Pearson korelasyon analizleri ile yorumlanmıştır. İçsel Pazarlama Ölçeğinin güvenirlik katsayısı 0,931; Örgütsel Bağl1lı Ölçeği 0,873 olmak üzere yüksek güvenilirlikte olduğu saptanmıştır.

\subsection{Bulgular ve Yorumlar}

Araştırma anketlerinden elde edilen sosyo-demografik bulgular, tanımlayıcı istatistikler, farklılık ve korelasyon analizleri aşağıda verilmiştir. 


\begin{tabular}{|c|c|c|c|c|c|c|c|}
\hline \multicolumn{8}{|c|}{ Tablo 1: Katılımcıların Sosyo-Demografik Özelliklere Göre Dağılımı } \\
\hline Değişkenler & & Frekans & $\%$ & Değişkenler & & Frekans & $\%$ \\
\hline \multirow{4}{*}{ Cinsiyet } & Erkek & 101 & 81,5 & & Yetkili/ Sorumlu & 24 & 19,4 \\
\hline & Kadın & 23 & 18,5 & & Tekniker/ teknisyen & 37 & 29,8 \\
\hline & $18-25$ & 3 & 2,4 & Işletmedeki & Mühendis & 8 & 6,5 \\
\hline & $26-35$ & 65 & 52,4 & Pozisyon & Yönetici/Ekip lideri & 34 & 27,4 \\
\hline \multirow[t]{4}{*}{ Yaş } & $36-45$ & 24 & 19,4 & & Memur/Temsilci & 21 & 16,9 \\
\hline & 46 ve üstü & 32 & 25,8 & & $1-5$ y1l & 23 & 18,5 \\
\hline & & & & Mesleki & $6-10$ yil & 42 & 33,9 \\
\hline & Lise & 13 & 10,5 & Deneyim & $11-15$ y1l & 20 & 16,1 \\
\hline Ĕ̈itim & Önlisans & 25 & 20,2 & & 16 yıl ve üzeri & 39 & 31,5 \\
\hline \multirow[t]{2}{*}{ Durumu } & Lisans & 67 & 54,0 & Medeni & Bekâr & 21 & 16,9 \\
\hline & Lisansüstü & 19 & 15,3 & Durum & Evli & 103 & 83,1 \\
\hline
\end{tabular}

Katılımcıların \%18,5 lik kısmı kadın, \%81,5'i ise erkek; \%35'i 26-35 yaş aralığında; \%54'ü lisans mezunu; \%83,1'i evlidir. Ankete kat1lanların \%29,8'i tekniker ve teknik eleman, $\% 27,4$ 'ü yönetici/ekip lideri pozisyonunda olan çalışanlardan oluşmaktadır. Katılımcıların \%33,9'u 6-10 y1l, \%31,5'i 16 y1l ve üzeri y1l mesleki deneyime sahiptir. Sosyo-demografik bulgular incelendiğinde katılımcıların büyük kısmı erkek ve önlisans ve daha üst eğitime sahip olduğu görülmektedir.

Tablo 2: İçsel Pazarlama Değişkenine Ait Ortalama ve Standart Sapma Değerleri

\begin{tabular}{|c|c|c|c|}
\hline \multicolumn{2}{|r|}{ İçsel Pazarlama Yargıları } & \multirow{2}{*}{$\begin{array}{c}\text { Ortalama } \\
3,9032\end{array}$} & \multirow{2}{*}{$\begin{array}{l}\begin{array}{l}\text { Standart } \\
\text { Sapma }\end{array} \\
, 98294\end{array}$} \\
\hline 1 & $\begin{array}{l}\text { Çalışanların beceri ve bilgi gelişimi, organizasyonumuzda } \\
\text { devam eden bir süreçtir. }\end{array}$ & & \\
\hline 2 & 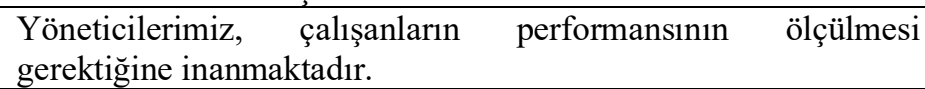 & 3,8455 & 1,04828 \\
\hline 3 & $\begin{array}{l}\text { Yöneticilerimiz, personel eğitimlerinin çok önemli olduğunu } \\
\text { düşünür. }\end{array}$ & 3,8387 & 1,03112 \\
\hline 4 & Kurumum vizyonunu çalş̧anlara iyi iletir. & 3,7581 & ,96585 \\
\hline 5 & $\begin{array}{l}\text { Kurumum çalışanlarda bilgi ve becerilerin gelişimini maliyetten } \\
\text { ziyade bir yatırım olarak görür. }\end{array}$ & 3,6855 & 1,11433 \\
\hline 6 & Kurumumuz çalışanlarına inanabilecekleri bir vizyon sunar. & 3,5081 & 1,10796 \\
\hline 7 & $\begin{array}{l}\text { Kurumumda çalışanlar görev rollerini yerine getirmek için } \\
\text { uygun şekilde eğitilmişlerdir. }\end{array}$ & 3,4597 & 1,12906 \\
\hline 8 & $\begin{array}{l}\text { Kurumum çalışanlarıyla iletişim kurmaya bu organizasyonda } \\
\text { büyük önem verir. }\end{array}$ & 3,4426 & 1,14307 \\
\hline 9 & $\begin{array}{l}\text { Kurumum çalışanların farklı ihtiyaçlarını karşılayabilecek } \\
\text { esnekliğe sahiptir. }\end{array}$ & 3,4032 & 1,07385 \\
\hline 10 & $\begin{array}{l}\text { Kurumumda mükemmel hizmet sunan çalışanlar çabaları için } \\
\text { ödüllendirilir. }\end{array}$ & 3,2742 & 1,24508 \\
\hline 11 & $\begin{array}{l}\text { Kurumumun vizyonuna en fazla katkı sağlayan çalışanların } \\
\text { performansları ölçülür ve ödüllendirilir. }\end{array}$ & 3,1048 & 1,23511 \\
\hline
\end{tabular}

Tablo 2'de içsel pazarlama ile ilgili ölçeğin ortalama ve standart sapma değerlerine yer verilmiştir. Tablo 2'yi yakından incelediğimizde, ortalamaların ağırlıklı olarak kararsız ile olumlu bir tutum arasında seyrettiği gözlemlenmektedir. Tabloya göre 3.9032 ile en yüksek ortalamanın "Çalışanların beceri ve bilgi gelişimi, organizasyonumuzda devam eden bir süreçtir." önermesinde; en düşük ortalamanın ise 3,1048 ile "Kurumumun vizyonuna en fazla katkı sağlayan çalışanların performansları ölçülür ve ödüllendirilir.” önermesinde toplandığı görülmektedir. 
Tablo 3: Örgütsel Bağl1lık Değişkenine İlişkin Ortalama ve Standart Sapma Değerleri

\begin{tabular}{|c|c|c|c|}
\hline \multicolumn{2}{|c|}{ Örgütsel Bağlılık Yargıları } & \multirow{2}{*}{$\begin{array}{l}\text { Ortalama } \\
4,0565 \\
\end{array}$} & \multirow{2}{*}{$\begin{array}{c}\begin{array}{c}\text { Standart } \\
\text { Sapma }\end{array} \\
, 98197 \\
\end{array}$} \\
\hline 1 & Kurumumun sorunlarını kendi sorunummuș gibi görürüm. & & \\
\hline 2 & Bu kurum kişisel anlamda benim için büyük önem taşıyor. & 4,0565 & 90439 \\
\hline 3 & Kurumumdan dışarıda gururla bahsediyorum. & 3,9919 & 1,06737 \\
\hline 4 & Kendimi kurumuma" duygusal olarak bağlı" hissediyorum. & 3,9516 & 95300 \\
\hline 5 & Kurumuma ait olduğum ile ilgili güçlü bir hissim var. & 3,9435 & ,97366 \\
\hline 6 & Kurum içerisinde kendimi "ailenin bir parçası " olarak görüyorum. & 3,9106 & ,98354 \\
\hline 7 & $\begin{array}{l}\text { Kendim istesem bile şimdi kurumumdan ayrilmak bana oldukça zor } \\
\text { gelir. }\end{array}$ & 3,9024 & 1,01960 \\
\hline 8 & $\begin{array}{l}\text { Kariyerimin geri kalanını bu kurumda harcamaktan mutluluk } \\
\text { duyarım. }\end{array}$ & 3,6210 & 1,20698 \\
\hline 9 & Kurumum benim sadakatimi hak ediyor. & 3,5772 & 1,07892 \\
\hline 10 & $\begin{array}{l}\text { Bu kurumdan ayrılmanın ciddi sonuçlarından bir tanesi mevcut } \\
\text { alternatiflerin kitlığıdır. }\end{array}$ & 3,5285 & 1,02689 \\
\hline 11 & $\begin{array}{l}\text { Benim yararıma bile olsa şu anda kurumumdan ayrılmanın doğru } \\
\text { olmayacağını düşünüyorum. }\end{array}$ & 3,3871 & 1,06466 \\
\hline 12 & Şimdi işimden ayrılma kararı alsam hayatımda çok şey alt üst olur. & 3,3659 & 1,21647 \\
\hline 13 & Şimdi bu $\mathrm{k}$ & 3,3577 & 1,11715 \\
\hline 14 & $\begin{array}{l}\text { Kurumumda çalışamaya devam etmemim temel nedenlerinden biri } \\
\text { de, ayrılmamın çok büyük kişisel fedakârlık gerektirmesidir. }\end{array}$ & 3,3333 & ,96383 \\
\hline 15 & $\begin{array}{l}\text { Eğer kurumuma bu kadar çok emek vermemiş olsaydım, başka bir } \\
\text { yerde çalışmayı düşünebilirdim. }\end{array}$ & 3,2602 & 1,13684 \\
\hline 16 & $\begin{array}{l}\text { Bu kurumdan ayrılma düşüncesinin bana çok az seçenek sunacağını } \\
\text { düşünüyorum. }\end{array}$ & 3,2358 & 1,00067 \\
\hline 17 & $\begin{array}{l}\text { Kurumumun içindeki insanlara olan sorumluluk hissimden dolay1 } \\
\text { bu kurumdan ayrılmam. }\end{array}$ & 3,1967 & 1,11072 \\
\hline 18 & Kurumuma karşı kendimi borçlu hissediyorum. & 3,1789 & 1,15256 \\
\hline 19 & Şu anda kurumumdan ayrılırsam kendimi suçlu hissederim. & 3,0968 & 1,17161 \\
\hline 20 & $\begin{array}{l}\text { Şu andaki kurumumda çalışmak için hiçbir zorunluluk hissi } \\
\text { duymuyorum. }\end{array}$ & 2,0565 & 1,03831 \\
\hline
\end{tabular}

Tablo 3 incelendiğinde, 4.0565 ile en yüksek ortalamanın "Kurumumun sorunlarını kendi sorunummuş gibi görürüm." ve "Bu kurum kişisel anlamda benim için büyük önem taşıyor." önermelerinde toplandığ 1 , en düşük ortalamanın ise 2,0565 ile "Şu andaki kurumumda çalışmak için hiçbir zorunluluk hissi duymuyorum.” önermesinde olduğu görülmektedir.

Tablo 4: Araştırma Ölçekleri ve Boyutlarının Ortalamalarının Dağılımı

\begin{tabular}{|c|c|c|c|c|c|}
\hline Ölçekler ve Boyutlar & $\mathbf{N}$ & Min. & Maks. & Ort. & Std. Sapma \\
\hline İsgören Gelişimi & 124 & 1,00 & 5,00 & 3,6581 &, 89143 \\
\hline Etkili İletişim & 122 & 1,00 & 5,00 & 3,5628 &, 92420 \\
\hline Ödül Ve Motivasyon & 123 & 1,00 & 5,00 & 3,4038 & 1,02274 \\
\hline İçsel Pazarlama & $\mathbf{1 2 1}$ & $\mathbf{1 , 0 0}$ & $\mathbf{5 , 0 0}$ & $\mathbf{3 , 5 4 7 7}$ & $\mathbf{8 4 8 5 5}$ \\
\hline Duygusal Bağlılık & 122 & 1,00 & 5,00 & 3,9450 &, 83308 \\
\hline Devam Bağlılık & 121 & 1,43 & 5,00 & 3,4262 &, 65750 \\
\hline Normatif Bağlılık & 121 & 1,33 & 5,00 & 3,2521 &, 72684 \\
\hline Örgütsel Bağlılık & $\mathbf{1 1 8}$ & $\mathbf{1 , 8 0}$ & $\mathbf{5 , 0 0}$ & $\mathbf{3 , 5 5 0 0}$ & $\mathbf{5 8 1 6 6}$ \\
\hline
\end{tabular}

Tablo 4'de görüldüğü üzere katılımcıların içsel pazarlama düzeyi (min.:1-max.:5)

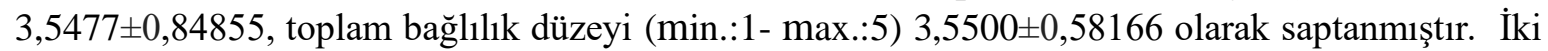
değerde ortalamanın biraz üzerinde ve kararsız ile olumlu bir tutum arasındadır. 
Tablo 5: Katılımcıların İçsel Pazarlama ve Örgütsel Bağlılık Düzeylerinin Sosyo-Demografik Değişkenlere Göre Farklılık Gösterip Göstermediğine İlişkin Student T Testi Analizi

\begin{tabular}{|c|c|c|c|c|c|c|c|}
\hline Ölçüt & Ölçekler & $\begin{array}{l}\text { Değişken } \\
\text { Adı }\end{array}$ & $\mathbf{N}$ & Ortal. & $\begin{array}{l}\text { Stand. } \\
\text { Sapma }\end{array}$ & $\mathbf{t}$ & $\mathbf{p}$ \\
\hline \multirow[t]{4}{*}{ Cinsiyet } & \multirow{2}{*}{ İçsel Pazarlama } & Kadın & 22 & 3,1860 & ,91620 & \multirow[t]{2}{*}{$-2,087$} & \multirow[t]{2}{*}{$0,046^{*}$} \\
\hline & & Erkek & 99 & 3,6281 & 81602 & & \\
\hline & \multirow[t]{2}{*}{ Örgütsel Bağll11k } & Kadın & 22 & 3,3205 & 45635 & \multirow[t]{2}{*}{$-2,459$} & \multirow[t]{2}{*}{$0,018^{*}$} \\
\hline & & Erkek & 96 & 3,6026 &, 59636 & & \\
\hline \multirow{4}{*}{$\begin{array}{l}\text { Medeni } \\
\text { durum }\end{array}$} & \multirow[t]{2}{*}{ İçsel Pazarlama } & Bekâr & 21 & 3,5931 & ,69688 & \multirow[t]{2}{*}{0,268} & \multirow[t]{2}{*}{0,789} \\
\hline & & Evli & 100 & 3,5382 & 87985 & & \\
\hline & \multirow[t]{2}{*}{ Örgütsel Bağll11k } & Bekâr & 20 & 3,5400 &, 50252 & \multirow[t]{2}{*}{$-0,084$} & \multirow[t]{2}{*}{0,933} \\
\hline & & Evli & 98 & 3.5520 & 59884 & & \\
\hline
\end{tabular}

$* \mathrm{P}<0,05$

Tablo 5 'te bazı sosyo-demografik değişkenlere göre araştırma ölçeklerine verilen cevapların t testi analizi incelendiğinde;

- Cinsiyet değişkeni bakımından içsel pazarlama ve örgütsel bağlllık düzeyinde istatistiksel olarak anlamlı bir farklılık olduğu $(\mathrm{p}>0,05)$ saptanmıştır $\left(\mathrm{H}_{2.1}\right.$ ve $\mathrm{H}_{3.1}$ hipotezleri kabul edilmiştir). Erkeklerin kadınlara göre daha yüksek düzeyde içsel pazarlama ve örgütsel bağlilık düzeyine sahip oldukları saptanmıştır.

- Medeni durum değişkeni bakımından içsel pazarlama ve örgütsel bağl1lık düzeyinde istatistiksel olarak anlamlı bir farkl11ık olmadığ $1(\mathrm{p}>0,05)$ saptanmıştır $\left(\mathrm{H}_{2.2}\right.$ ve $\mathrm{H}_{3.2}$ hipotezleri red edilmiştir). 
Tablo 6: Katılımcıların İçsel Pazarlama ve Örgütsel Bağlılık Düzeylerinin Sosyo-Demografik Değişkenlere Göre Farklılık Gösterip Göstermediğine İlişsin ANOVA Analizi

\begin{tabular}{|c|c|c|c|c|c|c|c|}
\hline Ölçüt & Ölçekler & Değişken Adı & $\mathbf{N}$ & Ort. & $\begin{array}{l}\text { Std. } \\
\text { Sapma }\end{array}$ & $\mathbf{F}$ & $\mathbf{p}$ \\
\hline \multirow{8}{*}{$\begin{array}{c}\text { Yaş } \\
\text { durumu }\end{array}$} & \multirow{4}{*}{$\begin{array}{l}\text { İçsel } \\
\text { Pazarlama }\end{array}$} & $18-25$ yaş & 3 & 3,4242 & 84469 & \multirow{4}{*}{2,294} & \multirow{4}{*}{0,082} \\
\hline & & $26-35$ yaş & 62 & 3,3739 & ,84259 & & \\
\hline & & $36-45$ yas & 24 & 3,6212 & 81869 & & \\
\hline & & 46 yaş ve üzeri & 32 & 3,8409 & ,83191 & & \\
\hline & \multirow{4}{*}{$\begin{array}{l}\text { Örgütsel } \\
\text { Bağl1lık }\end{array}$} & $18-25$ yaş & 3 & 3,3500 & ,27839 & \multirow{4}{*}{0,554} & \multirow{4}{*}{0,646} \\
\hline & & 26-35 yaş & 60 & 3,4975 & ,60628 & & \\
\hline & & $36-45$ yaş & 24 & 3,6438 & ,60744 & & \\
\hline & & 46 yaş ve üzeri & 31 & 3,5984 & ,53813 & & \\
\hline \multirow{10}{*}{ Meslek } & \multirow[t]{5}{*}{$\begin{array}{l}\text { İçsel } \\
\text { Pazarlama }\end{array}$} & $\begin{array}{l}\text { Yetkili/ } \\
\text { Sorumlu }\end{array}$ & 22 & 3,4380 & ,84335 & \multirow{5}{*}{1,339} & \multirow{5}{*}{0,260} \\
\hline & & $\begin{array}{l}\text { Tekniker/ } \\
\text { teknisyen }\end{array}$ & 37 & 3,7027 & ,87030 & & \\
\hline & & Mühendis & 8 & 3,7386 & ,64363 & & \\
\hline & & $\begin{array}{l}\text { Yönetici/ Ekip } \\
\text { lideri }\end{array}$ & 33 & 3,6088 & ,80143 & & \\
\hline & & $\begin{array}{l}\text { Memur/ } \\
\text { Temsilci }\end{array}$ & 21 & 3,2208 & ,92019 & & \\
\hline & \multirow[t]{5}{*}{$\begin{array}{l}\text { Örgütsel } \\
\text { Bağll11k }\end{array}$} & $\begin{array}{l}\text { Yetkili/ } \\
\text { Sorumlu }\end{array}$ & 23 & 3,6587 & ,67968 & \multirow{5}{*}{1,346} & \multirow{5}{*}{0,257} \\
\hline & & $\begin{array}{l}\text { Tekniker/ } \\
\text { teknisyen }\end{array}$ & 36 & 3,6431 & ,57223 & & \\
\hline & & Mühendis & 7 & 3,4571 & ,41173 & & \\
\hline & & $\begin{array}{l}\text { Yönetici/ Ekip } \\
\text { lideri }\end{array}$ & 32 & 3,5375 & ,53897 & & \\
\hline & & $\begin{array}{l}\text { Memur/ } \\
\text { Temsilci }\end{array}$ & 20 & 3,3100 & ,56838 & & \\
\hline \multirow{8}{*}{$\begin{array}{l}\text { Eğitim } \\
\text { Durumu }\end{array}$} & \multirow{4}{*}{$\begin{array}{l}\text { İçsel } \\
\text { Pazarlama }\end{array}$} & Lise & 13 & 3,9441 & 1,01947 & \multirow{4}{*}{2,242} & \multirow{4}{*}{0,087} \\
\hline & & Önlisans & 24 & 3,7273 & ,74049 & & \\
\hline & & Lisans & 65 & 3,3818 & ,86247 & & \\
\hline & & Lisansüstü & 19 & 3,6172 & ,70781 & & \\
\hline & \multirow{4}{*}{$\begin{array}{l}\text { Örgütsel } \\
\text { Bağlılık }\end{array}$} & Lise & 13 & 3,5269 & ,62136 & \multirow{4}{*}{3,934} & \multirow{4}{*}{$0,10^{*}$} \\
\hline & & Önlisans & 25 & 3,8860 & ,56227 & & \\
\hline & & Lisans & 63 & 3,4635 & ,56840 & & \\
\hline & & Lisansüstü & 17 & 3,3941 & ,47562 & & \\
\hline \multirow{8}{*}{$\begin{array}{l}\text { Toplam } \\
\text { mesleki } \\
\text { çalışma } \\
\text { süresi }\end{array}$} & \multirow{4}{*}{$\begin{array}{l}\text { İçsel } \\
\text { Pazarlama }\end{array}$} & $1-5$ y1l & 23 & 3,6245 & ,60446 & \multirow{4}{*}{2,162} & \multirow{4}{*}{0,096} \\
\hline & & $6-10$ yil & 39 & 3,2751 & 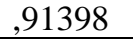 & & \\
\hline & & $11-15$ y1l & 20 & 3,6227 & ,74165 & & \\
\hline & & 16 y1l ve üzeri & 39 & 3,7366 & ,91239 & & \\
\hline & \multirow{4}{*}{$\begin{array}{l}\text { Örgütsel } \\
\text { Bağll11k }\end{array}$} & $1-5 \mathrm{y} 1 \mathrm{l}$ & 22 & 3,5909 & 38067 & \multirow{4}{*}{0,353} & \multirow{4}{*}{0,787} \\
\hline & & 6-10 y1l & 39 & 3,4718 & ,63327 & & \\
\hline & & $11-15$ y1l & 19 & 3,5711 & ,57719 & & \\
\hline & & 16 yıl ve üzeri & 38 & 3,5961 & 63548 & & \\
\hline
\end{tabular}

$* \mathrm{p}<0,05$

Tablo 6'te sosyo-demografik değişkenlere göre araştırma ölçeklerine verilen cevapların varyans analizi incelendiğinde;

- Eğitim durumu değişkenine göre örgütsel bağl1lık düzeyi dışında $(\mathrm{p}<0,05)$, yaş, meslek ve toplam mesleki çalışma süresi değişkenlerine göre çalışanların içsel pazarlama ve örgütsel bağlılık düzeyleri arasında istatistiksel düzeyde anlamlı bir farklılığın olmadığ 
saptanmıştır $(\mathrm{p}>0,05)$. Önlisans mezunu olanların lisans ve lisansüstü eğitim mezunu olanlara göre örgütlerine daha bağlı oldukları saptanmıştır $\left(\mathrm{H}_{3.5}\right.$ hipotezi kabul edilmiş; $\mathrm{H}_{2.1}, \mathrm{H}_{2.2}, \mathrm{H}_{2.3}, \mathrm{H}_{2.4}, \mathrm{H}_{2.5}, \mathrm{H}_{2.6}, \mathrm{H}_{3.1}, \mathrm{H}_{3.2}, \mathrm{H}_{3.3}, \mathrm{H}_{3.4}, \mathrm{H}_{3.6}$ hipotezleri red edilmiştir).

Tablo 7: İçsel Pazarlama ve Örgütsel Bağl1lık Arasındaki İlişkiye İlișkin Korelasyon Analiz

\begin{tabular}{|ll|c|c|c|c|}
\hline & & $\begin{array}{c}\text { Duygusal } \\
\text { Bağll11k }\end{array}$ & $\begin{array}{c}\text { Devam } \\
\text { Bağll11k }\end{array}$ & $\begin{array}{c}\text { Normatif } \\
\text { Bağll1k }\end{array}$ & $\begin{array}{c}\text { Toplam } \\
\text { Bağll1.k }\end{array}$ \\
\hline Ödül Ve & Pearson Correlation &, $620^{* *}$ &, 105 &, $361^{* *}$ &, $467^{* *}$ \\
Motivasyon & Sig. (2-tailed) &, 000 &, 253 &, 000 &, 000 \\
& $\mathrm{~N}$ & 121 & 120 & 120 & 117 \\
\hline Etkili İletişim & Pearson Correlation &, $756^{* *}$ &, 146 &, $487^{* *}$ &, $614^{* *}$ \\
& Sig. (2-tailed) &, 000 &, 114 &, 000 &, 000 \\
& $\mathrm{~N}$ & 120 & 119 & 119 & 116 \\
\hline İşgören Gelişimimi & Pearson Correlation &, $712^{* *}$ &, 114 &, $438^{* *}$ &, $567^{* *}$ \\
& Sig. (2-tailed) &, 000 &, 212 &, 000 &, 000 \\
& $\mathrm{~N}$ & 122 & 121 & 121 & 118 \\
\hline Toplam İçsel & Pearson Correlation &, $765^{* *}$ &, 108 &, $461^{* *}$ &, $595^{* *}$ \\
Pazarlama & Sig. (2-tailed) &, 000 &, 243 &, 000 &, 000 \\
& $\mathrm{~N}$ & 119 & 118 & 118 & 115 \\
\hline
\end{tabular}

**. Correlation is significant at the 0.01 level (2-tailed).

Tablo 7'de ölçekler arası ilişkileri ortaya koymak amacı ile korelasyon analizi sonuçları verilmiştir. Toplam içsel pazarlama ile toplam örgütsel bağl1lık arasında $(r=0,595, p<0,01)$ orta düzeyde aynı yönlü anlamlı bir ilişki saptanmıştır. Buradan da anlaşılacağı üzere örgütlerde içsel pazarlama düzeyinin artması, örgütsel bağlılı̆̆1 artırdığ1 söylenebilir. Diğer taraftan örgütsel bağlılığın alt boyutlarından duygusal bağl1lık ile içsel pazarlama arasında $(r=0,765, p<0,01)$ yüksek bir ilişki, normatif bağlılık ile içsel pazarlama arasında $(\mathrm{r}=0,461, \mathrm{p}<0,01)$ orta düzey bir ilişki saptanırken; devam bağlılığı ile içsel pazarlama arasında $(r=0,108, p>0,05)$ istatistiksel olarak anlamlı bir ilişki saptanmamıştır.

\section{Sonuç ve Öneriler}

Küreselleşmeyle yaşanan hılı değişimler ve gelişmeler yönetim anlayışında da değişikliklere ve yeni anlayışların ortaya çıkmasına neden olmaktadır. Bu yeni anlayışlardan biri de içsel pazarlamadır. Bu anlayış, dış müşteriye hizmet vermenin kalitesinin ve onun memnuniyetinin, iç müşterinin (yani çalışanların) memnuniyetinden geçtiğini ortaya koymaktadır. İçsel pazarlamanın önemli bir etkisi de çalışanların örgütsel bağlılıklarının artırılmasına olan katkısıdır. İçsel pazarlamanın örgütsel bağlılıkla olan ilişkini ortaya koymak amacıyla yapılan bu çalışmada, Konya ilinde bir telekomünikasyon kurumunda görev yapan çalışanlara anket uygulanmıştır. $\mathrm{Bu}$ çalışmanın sonuçları kısaca aşağıda verilmiştir.

- Araştırmaya katılmaya gönüllü olan 124 kişi üzerinde yapılan bu çalışmada; katılımcıların \%18,5 lik kısmı bayan, \%81,5'i ise erkek; \%35'inin 26-35 yaş aralığında; \%54'ü lisans eğitimi mezunu; \%83,1'i evli; \%29,8'i tekniker ve teknik eleman, \%27,4'ü yönetici/ ekip lideri pozisyonunda olan çalışan; \%33,9'u 6-10 yıl, \%31,5'i 16 yıl ve üzeri yıl mesleki deneyime sahip olduğu saptanmıştır. Sosyo-demografik bulgulara bakılırsa katılımcıların çoğunluğunun erkek ve ön lisans ve daha üst eğitime sahip olduğu görülmektedir.

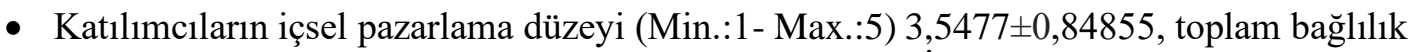
düzeyi (Min.:1- Max.:5) 3,5500 $\pm 0,58166$ olarak saptanmıştır. İki değerde ortalamanın biraz üzerinde ve kararsız ile olumlu bir tutum arasındadır. 
- Erkeklerin kadınlara göre daha yüksek düzeyde içsel pazarlama ve örgütsel bağlılık düzeyine sahip oldukları saptanmıştır $(\mathrm{p}>0,05)$. Erkeklerin çalışma ve aileye zorunluluğunun olması, bu sonucun ortaya çıkmasında etkili olduğu ileri sürülebilir.

- Önlisans mezunu olanların lisans ve lisansüstü eğitim mezunu olanlara göre örgütlerine daha bağlı oldukları saptanmıştır ( $>>0,05)$.

İçsel pazarlama ile örgütsel bağlılık kavramları arasındaki ilişkiye ilişkin veriler incelendiğinde; toplam içsel pazarlama ile toplam örgütsel bağlılık arasında $(r=0,595, p<0,01)$ orta düzeyde aynı yönlü anlamlı bir ilişki saptanmıştır. Buradan da anlaşılacağı üzere örgütlerde içsel pazarlama düzeyinin artması, örgütsel bağlılığı da artırdığını söylenebilir. Diğer taraftan örgütsel bağlılığın alt boyutlarından duygusal bağlılık ile içsel pazarlama arasında $(r=0,765, p<0,01)$ yüksek bir ilişki, normatif bağl1lı ile içsel pazarlama arasında $(\mathrm{r}=0,461, \mathrm{p}<0,01)$ orta düzey bir ilişki saptanırken; devam bağlılığı ile içsel pazarlama arasında $(r=0,108, p>0,05)$ istatistiksel olarak anlamlı bir ilişki saptanmamıştır. Bu da göstermektedir ki, içsel pazarlama faaliyetleri, çalışanların örgüte karş1 gönüllü ve kuvvetli bir bağl1lık türü olan duygusal ve normatif bağl1l1klarını arttırmakta; örgütte kalmalarını bir zorunluluk olarak gören devam bağlılığını ise etkilememektedir. Benzer olarak, Kocaman vd. (2013) tarafindan konaklama işletmelerinde, Demir vd. (2008) akademisyenler üzerinde ve Yüce ve Kavak (2017) tarafından öğretmenler üzerinde, Yarımoğlu ve Ersönmez, (2017) tarafından banka çalışanları üzerinde yapılan çalışmalarda örgütsel bağlılıkla içsel pazarlam arasında pozitifi yönlü ilişki saptamıştır.

İşletmelerde gerek içsel pazarlama faaliyetlerinin yürütülmesinde gerekse örgütsel bağlılığın artırılmasında etkili olan birçok faktör olmakla birlikte içsel pazarlama faaliyetlerinin ve çalışan bağlılığının artırılmasında yöneticilerin sorumlululuğu oldukça büyüktür. Yöneticilerin çalışanlarının memnuniyetini sağlamaları ve işyerinde onları motive etmeleri için klasik yönetim anlayışının dışına çıkmaları gerekmektedir. Bunu başarabilirlerse hem sunulan hizmet kalitesi artacak hem de iç ve dış müşteri memnuniyeti sağlanacaktır.

Sonuç olarak içsel pazarlama ve örgütsel bağl1lık kavramları, örgüt yönetiminde önemli ve dikkate alınması gereken unsurlardan biridir. Örgütlerde yöneticilik yapacak kişilerin içsel pazarlama ve örgütsel bağlılık konularında, hassas davranmaları, bu konuda eğitim almaları ve bu eğitimden edindikleri kazanımları örgütlerinde uygulamaları uygun olacaktır.

\section{Kaynakça}

Akıncı, Z. (2002). Turizm sektöründe işgören iş tatminini etkileyen faktörler: Beş yıldızlı konaklama işletmelerinde bir uygulama, İktisadi ve İdari Bilimler Fakültesi Dergisi, Akdeniz Üniversitesi, S.4, 1-25.

Arnet, D., Laviere, D. ve Mclane, C. (2002). Using job satisfaction and pride as internal marketing, cornel hotel and restaurant administration quarterly. 43(2), 87-96.

Bakan, İ. (2011). Örgütsel Bağlılık, 1. Baskı, Gazi Kitapevi, Ankara.

Balay, R. (2000). Yönetici ve Öğretmenlerde Örgütsel Bağlılık. Ankara: Nobel Yayın Dağıtım, Yayın No: 206.

Bayram, L. (2005). Yönetimde yeni bir paradigma: Örgütsel bağlılık. Sayıştay Dergisi, say1, 59.

Berry, L. L. (1981). The employee as customer. Journal of retail banking, 3(1), 33-40.

Bowen, D. and Schneider, B. (2014). A service climate synthesis and future research agenda. Journal of Service Research, 17(1), 5-22. 
Chordiya, R., Sabharwal, M. ve Goodman, D. (2017). Affective organizational commitment and job satisfaction: a cross-national comparative study. Public Administration, 95(1),178-195.

Çakınberk, A., Derin, N. ve Demirel, E. T. (2011). Vizyoner liderlik 1şı̆̆ında örgütsel bağl1lık. Asitan Yayınc1lık, Sivas.

Demir, H., Usta, R. ve Tarhan, O. (2008). İçsel pazarlamanın örgütsel bağll1ık ve iş tatminine etkisi. Hacettepe Üniversitesi İktisadi Ve İdari Bilimler Fakültesi Dergisi, 26(2), 135-161.

Demirel, Y. (2009). Örgütsel bağl1lığın iç hizmet kalitesi üzerine etkisi: Kamu ve özel sektör çalışanları üzerine bir araştırma, Dumlupınar Üniversitesi Sosyal Bilimler Dergisi, (23), ss. 269-281.

Doğan, S. ve Kılıç, S. (2008). İlişki yönetiminde iç ve dış müşteri memnuniyetinin sağlanması, Karamanoğlu Mehmetbey Üniversitesi Sosyal ve Ekonomik Araştırmalar Dergisi, 2008(1), 60-87.

Doukakis, I. P. ve Kitchen, P.J. (2004), Internal marketing in UK Banks: Conceptual legitimacy or window dressing? The internal journal of bank marketing, 22(6), 421-452.

Durna, U. ve Eren, V. (2005). Üç bağl1lık unsuru ekseninde örgütsel bağl1lık. Doğuş Üniversitesi Dergisi, 6(2), 210-219.

Dündar, İ. P. ve Fırlar, B.G. (2006). İçsel pazarlama ve toplam kalite yönetimi Türkiye'deki ulusal basın işletmelerinin değerlendirilmesine yönelik bir araştırma. Türk Dünyası Sosyal Bilimler Dergisi, Ahmet Yesevi Üniversitesi, S.36, s.131-153.

Eğriboyun, D. (2014). Ortaöğretim okullarında görev yapan yönetici ve öğretmenlerin örgütsel destek ve örgütsel bağlılıkları arasındaki ilişki, Sosyal Bilimler Elektronik Dergisi, Gümüşhane Üniversitesi, S.9, s.27- 52.

Elsamen, A. A. ve Alshurideh, M. (2012). The impact of internal marketing on internal service quality: A case study in a Jordanian pharmaceutical company, International Journal of Business and Management, C.7, S.19, s.84-95.

Eren, E. (2015). Örgütsel Davranış ve Yönetim Psikolojisi, Beta Basım Yayın Dağıtım, İstanbul.

Greene, W. E., Walls, G. D. and Schrest, L. J. (1994). Internal marketing: the key to external marketing success. Journal of Services marketing, 8(4), 5-13.

Imran, M. ve Binti Aziz, A. (2017). Religiosity and Organizational Commitment: A Conceptual Framework.

Ismaila, W., Sheriffb, N.M., (2016), Impact of internal marketing on job satisfaction among bank employees in Yemen, 3rd International Conference on Business and Economics, 21 - 23 September.

Izgar, H. (2003). Endüstri ve Örgüt Psikolojisi. 1. Bask1, Konya: Eğitim Kitabevi Yayınları.

İbicioğlu, H. (2000). Örgütsel bağll1ıkta paradigmatik uyumun yeri. İktisadi ve İdari Bilimler Fakültesi Dergisi, Dokuz Eylül Üniversitesi, C.15, S.1, 13-22.

İnce, M. ve Gül, H. (2005). Yönetimde yeni bir paradigma: Örgütsel bağlllık. Konya: Çizgi Kitabevi.

İşler, D. B. ve Özdemir, Ş. (2010). Hastane işletmelerinde içsel pazarlama yaklaşımının iş tatmini ve örgütsel bağll11k üzerine etkisi: Isparta ili örneği. Hacettepe Sağllk İdaresi Dergisi, 13(2), 115-142 
Karim, N. H. A. ve Noor, N. H. N. M. (2017). Evaluating the psychometric properties of Allen and Meyer's organizational commitment scale: A cross cultural application among Malaysian academic librarians. Malaysian Journal of Library \& Information Science, 11(1), 89-101.

Kitapçı, H. ve Elçi, M. (2007). Quality culture, ethical climate, person-organisation fit and organisational commitment: an empirical investigation. Journal of Global Strategic Management, 1(1), 142-150.

Kocaman, S., Durna, U. ve İnal, M., E. (2013). Konaklama işletmelerinde içsel pazarlama uygulamalarının örgütsel bağlılığa etkisi: Alanya Örneği, Uluslararası Alanya Işsletme Fakültesi Dergisi, Y11:2013, C:5, S:1, 21-29

Kotler, P. (2003). "Pazarlama Yönetimi”, Beta Yayınc1lı, İstanbul.

Kotler, P. (2005). A'dan Z' ye Pazarlama, Media Cat Kitapları, Kapital Medya Hizmetleri, 7. Bask1, İstanbul.

Köse, H. ve Özer, G. (2013). Profesyonel özelliklerin desteklenmesinin örgütün adaptif performansına etkisi: Örgütsel bağl1lığın aracılık rolünün yapısal eşitlik modeli ile testi, Business and Economics Research Journal, C.4, S.4, s.87-102.

Mercurio, Zachary A. (2015). Affective commitment as a core essence of organizational commitment an integrative literature review. Human Resource Development Review. 14 (4), 389-414. doi:10.1177/1534484315603612. ISSN 1534-4843.

Mowday, R. T., Porter, L. W. and Steers, R. M. (2013). Employee-organization linkages: The psychology of commitment, absenteeism, and turnover. Academic press.

Noe, R. A. (1999). İnsan Kaynaklarının Eğitimi ve Gelişimi. C. Çetin (Çev.). İstanbul: Beta Yayınları.

Opoku, R. A., Atuobi-Yiadom, N., Chong, C. S. and Abratt, R. (2009). The impact of internal marketing on the perception of service quality in retail banking: A Ghanaian case, Journal of Financial Services Marketing,13(4), pp:317-329.

Özalp, İ. (1994). İşletmelerde Yönetim, Fonksiyonlar ve Organizasyon. Baytaş Yayıncılık, Ankara.

Pinks, G. J. (1992). Facilitating organizational commitment through human resource practices. Industrial Relations Centre, Queen's University.

Rafiq, M. and Ahmed, P.K. (2000) Advances in the internal marketing concept: Definition, synthesis and extension. Journal of services marketing, 6, 449-462.

Reichers, A. E. (1985). A review and reconceptualization of organizational commitment. Academy of management review, 10(3), 465-476.

Sezgin, K. ve Ünlüönen K. (2011). Mutfak personelinin hizmet içi eğitiminin örgütsel bağl1lik ve iş tatminine etkisi üzerine bir uygulama. İșletme Araştırmaları Dergisi, C.3, S.2, 3-16.

Tekin, Ö. A., Aydın, A. Özmen, M. ve Aykaşlı M. Y. (2014). Tükenmişlik sendromu ve örgütsel bağl1lık: Su ürünleri işletmeleri üzerinde bir araştırma. Sosyal Bilimler Enstitüsü Dergisi. Dokuz Eylül Üniversitesi, C.16, S.1, 135-158.

Tutar, H. (2009). Örgütsel İletişim. 2. Baskı. Ankara: Seçkin Yayıncılık.

Urk, M. (2015). İçsel pazarlama uygulamalarının çalışan bağlılığı ile müşteri ve şirket performansına etkisinin analizinde kişilik özelliklerinin düzenleyici rolü, Doktora Tezi, Haliç Üniversitesi Sosyal Bilimler Enstitüsü.

Uygur, A. (2015). Örgütsel Bağlılık ve İşe Bağl1lık. Barış Platin Kitabevi, Ankara. 
Varinli, İ. (2008). Pazarlamada Yeni Yaklaşımlar, Detay Yayıncılık, Ankara.

Varinli, İ. (2012). Pazarlamada Yeni Yaklaşımlar. Ankara: Detay Yayıncılık.

Yarımoğlu, E. K. ve Ersönmez, N. (2017). İçsel pazarlama faaliyetlerinin iş tatmini ve örgütsel bağl1lı üzerindeki doğrudan etkisi: Bir kamu bankası örneği. Doğuş Üniversitesi Dergisi, 18(1), 79-98.

Yüce, A. ve Kavak, O. (2017). İçsel pazarlama faaliyetlerinin örgütsel bağlllık ve işten ayrılma niyeti üzerindeki etkisi: Bir araştırma, Balkan ve Yakın Doğu Sosyal Bilimler Dergisi, 2017: 03 (03).

Zeithaml, V., Berry, L. and Parasuraman, A. (1996). The behavioral consequences of service quality, Journal of Marketing, 60(2), 31-46. 